\title{
Menyiapkan Indonesia Pasca IMF
}

\author{
Harwanto Dahlan
}

The writer of the following article explains that Indonesia will end the IMF role at the end of this year. The exit strategy policy that will be conducted by indonesia emerges debating between pros and conts. But the main problem that should be carry out in this context is how to prepare ways so IMF will not come. The economy crisis in Indonesia actually causes the failure in realizing process of Indonesia government. So the important ways that should be done, Indonesia needs good governance and clean government. In addition, Indonesia actually will realize development as trusted by The Constitution 1945.

Indonesia akan menghentikan peran IMF Isebagai 'dokter' persoalan ekonomi makro pada akhir tahun ini. Selain karena sudah diamanatkan MPR, indikator ekonomi makro yang terus membaik dan cadangan devisa yang meningkat juga menambah kepercayaan kita untuk segera memu-tuskan kerjasama program dengan IMF. Kebijakan exit strategy ini sempat mengundang perdebatan karena ada pihak yang masih tetap menginginkan per-panjangan kerjasama dengan IMF, ada yang menghendaki pemutusan total, dan ada yang di antara keduanya. Pilihan pemerintah adalah di antara keduanya. Sebagai sebuah exit strategy yang sudah dipilih oleh pemerintah, pilihan tersebutharus dijalankan. Namun di luar itu, persoalan yang sangat penting yang dihadapi oleh Indonesia pasca IMF adalah bagaimana menyiapkan upayaupaya untuk mem-pertahankan momentum yang sudah diperoleh agar perekonomian tidak lagi terpunuk dan menjadikan IMF datang lagi. Mengingat keterpurukan ekonomi Indonesia lebih banyak disebabkan oleh kesalahan dalam menjalankan proses pemerintahan, maka upaya yang penting yang harus dilakukan adalah kesungguhan untuk melaksanakan proses pemerintahan yang baik (good governance) menuju terciptanya pemerintahan yang bersih (clean government).

\section{Keberhasilan Ekonomi Makro}

Program pemulihan ekonomi makro Indonesia dinilai Pemerintah cukup sukses sehingga kita bisa melihat tampilan ekonomi makro yang membaik. Cadangan devisa yang dipunyai Indonesia meningkat menjadi 34 milyar dollar. Sedangkan utang baru melalui IMF 'hanya' 9 milyar dollar. Nilai tukar rupiah terhadap dollar juga relatif stabil. Inflasi juga terkendali. Penerimaan APBN, khususnya melalui pajak juga meningkat. Hal-hal ini menjadikan Pemerintah optimis untuk tidak lagi tergantung pada IMF.

Meskipun indikator perekonomian cukup menjanjikan, kita harus cermat dalam melihat tampilan ekonomi makro seperti ini karena peningkatan devisa yang sekaligus dibarengi dengan utang baru sebesar 9 milyar dollar bisa mengindikasikan bahwa tambahan devisa bersifat semu. Artinya devisa meningkat karena adanya utang baru. 
Selain itu bisa juga devisa kita utuh karena beberapa kewajiban membayar utang yang jatuh tempo dijadwal ulang sehingga kita sebenarnya hanya menunda kewajiban pembayaran. Karena itu harus dipertanyakan darimana Pemerintah memperoleh tambahan devisa? Apabila penambahan devisa berasal dari meningkatnya ekspor, maka kita juga harus melihat komoditas yang diekspor. Komoditas ekspor yang hanya bersifat penjualan hasil industri ekstraktif, alias tinggal ambil dari alam seperti minyak dan gas bumi, belum mencerminkan realitas kekuatan ekonomi karena komoditas industri ekstraktif bisa cepat habis dan harganya sangat fluktuatif. Nilai tukar rupiah terhadap dollar AS yang relatif stabil bișa terjadi karena adanya intervensi Bank Indonesia atau lebih banyak dipengaruhi oleh stagnannya kondisi ekonomi Amerika Serikat sendiri.

Oleh karena itu membaiknya indikator perekonomian yang sesungguhnya belum riil ini tampaknya menjadikan Pemerintah RI merasa lebih aman memilih opsi post program monitoring.(PPM) daripada melunasi utang kepada IMF dan menghentikan keterlibatan IMF dalam penataan ekonomi makro Indonesia. Indonesia masih kuatir bahwa pada masa-masa yang akan datang tetap akan ada kemungkinan kesulitan ekonomi, khususnya karena pengaruh luar (external shock). PPM adalah program di mana Indonesia nanti akan terus melakukan konsultasi dengan staf IMF tentang kondisi dan prioritas kebijakan ekonominya, termasuk konsistensi kebijakan ekonomi Indonesia dalam jangka menengah dan implikasinya terhadap kemampuan Indonesia membayar kembali pinjaman melalui IMF. Diskusi ini akan dilaporkan kepada Badan Eksekutif dua tahun sekali. IMF juga menyediakan bantuan teknis apabila diminta.
Dengan PPM Indonesia tidak perlu membayar hutang yang diperoleh melalui IMF sekaligus sebesar 9,7 milyar dollar. Indonesia masih tetap mempertahankan posisi ini karena kekuatiran bahwa pelunasan hutang-yang pasti menggunakan devisa-akan berimplikasi pada stabilitas ekonomi makro, khususnya apabila ada hal-hal yang tidak bisa diperkirakan seperti kasus pemboman Hotel JW Marriot. Pilihan atas PPM sebenarnya masih tetap menjadikan IMF sebagai 'dokter' yang siap panggil apabila 'pasien' yang bernama Indonesia pada suatu saat kambuh lagi krisis ekonomi makronya. Ini mengindikasikan bahwa Indonesia belum bisa lepas dari IMF sepenuhnya. Kalau ada yang mengatakan "lulus", maka mestinya konsekuensinya adalah benar-benar lepas dari IMF sebagai pasien, dan hanya menjadi anggota biasa. Sebagaimana diketahui, anggota biasa IMF hanya boleh utang di bawah kuota yang sudah ditetapkan. Untuk Indonesia kuota hanya sekitar 2 milyar dollar. Pinjaman yang lebih dari kuota menunjukkan status sebagai pasien.

Apapun pilihannya, Pemerintah telah berkomitmen untuk tidak menambah utang lagi melalui jalur IMF karena sudah ada jalurjalur lain seperti CGI (Consultative Group on Indonesia) atau secara bilateral dan komersial. Dengan komitmen itu Indonesia benar-benar harus sehat secara umum. Berdasarkan apa yang dipunyai Indonesia, bukan sebuah kesulitan besar kalau Indonesia harus mengembalikan pinjaman ke IMF. Misalnya, Indonesia masih memiliki cadangan gas bumi sebesar 170 triliun kaki kubik, yang tentunya merupakan sumber perolehan devisa. Kekayaan lain, baik hasil minyak yang mencapai sekitar 1,5 juta barrel per hari, hasil hutan, maupun hasil kekayaan laut, sebenarnya masih cukup menjadi potensi untuk memajukan Indone- 
sia. Dengan potensi kekayaan seperti itu, Indonesia pasca IMF tentunya tidak perlu kuatir. Syaratnya hanyalah pemerintah benar-benar mempunyai komitmen untuk menggunakan kekayaan alam untuk sebesar-besarnya kemakmuran rakyat.

Bagaimana Indonesia harus mempertahankan indikator-indikator kesehatan ekonominya? Selain cara internal ekonomi, upaya-upaya suportif khususnya menciptakan pemerintahan yang bersih (clean government) sangat mendesak untuk dilakukan mengingat sebab utama persoalan ekonomi indonesia adalah buruknya kebijakan. Sejarah telah menunjukkan bahwa keterpurukan ekonomi Indonesia tidak disebabkan karena miskin sumberdaya tetapi lebih banyak disebabkan oleh kesalahan pengelolaan.

\section{Belajar dari Kesalahan}

Sepertinya bangsa kita ini tidak belajar dari kenyataan bahwa kita ini miskin bukan karena tidak mempunyai sumberdaya tetapi karena sumberdaya yang kita punyai itu jauh lebih banyak dinikmati orang lain. Dalam kasus yang terjadi masa belakangan inipun, salah satu penyebab terpuruknya ekonomi Indonesia adalah mengalirnya kekayaan kita ke luar Indonesia untuk dinikmati orang-orang asing. Dulu, pada bentuk awal, negaranegara lain menggunakan cara berupa penguasaan langsung sumber-sumber daya alam kita, misalnya hasil pertanian, minyak dan mineral. Dengan cara yang dikenal sebagai penjajahan tersebut $V O C$ menguras harta kekayaan Nusantara untuk menopang kehidupan dan kesejahteraan bangsa Belanda. Begitu pula Jepang yang secara lebih brutal menguasai Indonesia untuk menopang industri perangnya. Dengan penjajahan tersebut kekayaan Indonesia mengalir keluar tanpa bisa dinikmati bangsa Indonesia.
Setelah Indonesia merdeka dan penjajahan tidak lagi menjadi trend penguasaan sumberdaya alam, diperkenalkanlah yang namanya pem-bangunan. Langkah pertama pembangunan adalah mengalirnya hutang luar negeri untuk mempersiapkan tulang punggungnya: industrialisasi. Industrialisasi di Indonesia yang sesungguhnya adalah relokasi industri dari negara-negara maju seperti Jepang merupakan upaya untuk mempertahankan keuntungan melalui pemindahan kerugian. Industri yang sudah kadaluwarsa di negeri mereka karena teknologi yang dipakai sudah usang, terlalu menimbulkan polusi seperti industri tekstil, atau industri yang tidak menguntungkan lagi (sunset industry) dijual ke negara seperti Indonesia dan memberi keuntungan besar karena bersifat ISI (Industri Substitusi Impor) alias untuk pasar dalam negeri Indonesia. Keuntungan pun mengalir ke negara-negara maju sehingga sekali lagi sumberdaya, kali ini finansial, tidak berputar di Indonesia.

Keuntungan besar yang mengalir keluar dipelihara dengan kebijakan yang dikenal sebagai foreign direct investment, yaitu investasi langsung pada industri manufaktur. Jepang. Taiwan, Korea dengan agresif menanamkan investasinya ke indonesia dalam bidang industri manufaktur, khususnya industri manufaktur dengan teknologi yang tidak lagi diaplikasikan di negara asal mereka atau sekedar melakukan perakitan (assembling). Industri garmen, sepatu dan elektronika merupakan contoh. Akibatnya tenaga kerja yang terserap di bidang ini adalah tenaga kerja yang tidak perlu ahli karena hanya menghasilkan produk melalui sistem ban berjalan. Melimpahnya tenaga kerja jenis ini menjadikan upah buruh sangat rendah. Dan untuk mengantisipasi sejak awal akan kemungkinan buruh yang rewel, maka 
tenaga kerja yang lebih banyak dipakai adalah perempuan. Bagi pemillik modal, menekan upah buruh sama dengan mengurangi biaya produksi dan dengan sendirinya bisa mendongkrak keuntungan.

Upaya mengambil surplus bangsa Indonesia terus'berlanjut. Sasarannya berganti kepada orang-orang yang punya uang lebih, atau bahkan pemerintah. Melalui bursa efek, jual beli saham, investasi portofolio, future tradings dan permainan sekuritas, merekamereka yang sudah berpengalaman berusaha untuk menjadikan dunia yang masih baru dan belum diatur dengan baik oleh pemerintah Indonesia ini sebagai lahan menangguk keuntungan. Terakhir, perdagangan valuta asing telah secara tragis memporakporandakan perekonomian Indonesia. Perdagangan valuta asing tidak memberi penghasilan kepada pemerintah karena perdagangan tersebut meskipun volumenya bisa mencapai 50 juta dollar per hari, tetapi tidak kena pajak. Bahkan spekulasi melalui valas sangat sering memaksa pemerintah melakukan intervensi dengan menjual cadangan dollarnya. Intervensi pemerintah melalui Bank Indonesia ini meskipun mencegah naiknya kurs dollar, tetap saja merugikan pemerintah karena membuat pemerintah menjual dollarnya di bawah harga pasar. Ditambah lagi dengan pencurian modern yang secara sistematis dilakukan oleh unsur dalam negeri Indonesia sendiri yang populer dengan istilah kegiatan mencari rente (rent-seeking activities) seperti korupsi sampai kejahatan pencucian uang (money laundering).

Contoh-contoh di atas seharusnya sudah menyadarkan seluruh komponen bangsa ini untuk memperbaikinya. Dengan melihat negara-negara tetangga seperti Singapura dan Malaysia, atau bahkan Cina sekarang ini, tidak cukupkah bahan-bahan pelajaran bagi bangsa kita? Ataukah kita harus menunggu sampai benar-benar bangsa ini terpecah belah, miskin, dan tidak lagi punya harta benda untuk bisa belajar?

\section{Menciptakan Good Governance}

Beruntungnya, persoalan yang dihadapi bangsa kita pernah dijumpai oleh bangsa lain. Dengan demikian sudah ada dasar teoretis untuk menghadapi persoalan tersebut berdasar pada apa yang sudah dipelajari para akademisi. Menurut para akademisi-dan juga didukung oleh lembaga PBB seperti UNDP dan Bank Dunia- "resep" utama perbaikan kualitas berbangsa adalah perbaikan kualitas pemerintahannya. Mengingat persoalanpersoalan yang dihadapi negara-negara berkembang adalah persoalan yang selalu berkait dengan pemerintah yang kurang populer di mata rakyat, kurang berpihak pada rakyat, korup dan bahkan menganiaya rakyatnya sendiri, maka perbaikan kuallitas pemerintahan bisa ditempuh dengan cara menerapkan prinsip pemerintahan yang bersih melalui proses pemerintahan yang baik (good governance).

Good governance bisa dijalankan dengan dasar 5 (lima) hal yaitu transparency, responsibility, accountability, participation, dan responsiveness. Transparan mempunyai pengertian jelas, baik tujuan maupun cara mencapainya. Dalam banyak kasus, yang terjadi adalah the end justifies the means alias tujuan menghalalkan cara. Akibatnya kità lihat banyak penyimpangan. Kasus BLBI, Rekening 502, pembelian Sukhoi, adalah sebagian kecil contoh di mana prosedur standar pelaksanaan kebijakan tidak dilakukan. Belum lagi adanya kebijakan memutar uang seperti dana pensiun, jamsostek, dan lain-lain. Aksesibilitas informasi oleh publik juga merupakan syarat transparansi. Tetapi sudah bukan rahasia lagi kalau masyarakat 
tidak mempunyai akses, bahkan sekedar untuk mengetahui, berapa besar dana pemerintah atau dana masyarakat sendiri diikutsertakan dalam berbagai kegiatan bisnis. Berapa besar keuntungannya, kemana keuntungan itu mengalir dan untuk siapa keuntungan itu dimanfaatkan.

Responsibility (pertanggungjawaban) mensyaratkan pejabat-pejabat yang bertanggungjawab atas tugas negara yang dibebankan kepadanya termasuk resikoresiko yang mungkin menjadi konsekuensi jabatan. Bahkan sebelum jabatan itu diberikan, tanggungjawab juga bisa diartikan sebagai kesesuaian antara kapabilitas dan jabatan. Ini sangat berguna untuk memperbaiki kebiasaan nepotisme di negara berkembang yang sangat sering memberi posisi kepada orang tanpa kapabilitas yang cukup karena orang tersebut adalah saudara, teman dekat, atau sekedar sesama alumnus. Dalam kecenderungan terakhir kita justru melihat bagaimana pejabat publik dipilih dari siapa yang bisa menyediakan dana paling banyak. Memang, ada yang menolak kalau disebut money politics, hanya sekedar' 'dana konsolidasi.'

Accountability akan lebih tepat apabila diartikan amanah. Orang yang amanah adalah orang yang bisa mengemban tanggung jawab (responsibility) yang diberikan. Dengan sikap ini orang akan berusaha keras dengan segala inisiatif dan kreativitasnya mewujudkan tugasnya kedalam sebuah hasil yang optimum. Sikap amanah bisa digunakan untuk memperbaiki kondisi Indonesia yang sangat sering memilih orang yang ABS (Asal Bapak Senang), yang menerapkan pola-pola kepemimpinan tanpa inisiatif dan kreativitas, atau bahkan cenderung defensif mempertahankan posisi meski sudah babak belur dalam posisi tersebut. Orang yang tidak amanah tidak berorientasi pada prestasi pencapaian (achievement). la hanya mengejar target, khususnya yang berkait dengan kepentingan pribadi, atau paling jauh kelompoknya.

Lalu bagaimana pejabat-pejabat publik dipilih dan bagaimana mereka mengambil kebijakan diperbaiki dengan partisipasi. Memang selama ini sudah ada bentuk partisipasi rakyat dalam memilih pejabat publik, namun tentunya belum cukup dan belum baik. Karena itu upaya untuk memilih presiden secara langsung, memilih wakil rakyat dengan sistem yang lebih baik mengarah ke sistem distrik, bahkan usulan agar gubernur dan bupati juga dipilih secara langsung oleh rakyat, haruslah didukung. Upaya meningkatkan partisipasi rakyat dalam pembuatan keputusan juga harus terus dilakukan, minimal melalui mekanisme pengawasan atau uji publik. Bila hal-hal seperti ini dikembangkan dan dibudayakan, maka pejabat publik tidak akan berbuat semaunya dalam membuat keputusan. Sangat sering rakyat diabaikan dalam pembuatan kebijakan yang menyangkut nasib mereka. Kenaikan tarif listrik, air dan telepon, meroketnya harga BBM, meningkatnya ongkos transportasi, semua diputuskan tanpa adanya partisipasi publik. Sebuah contoh yang pernah terjadi di Boston, misalnya, ketika pemerintah daerah negara bagian Massachusetts ingin menaikkan ongkos kereta bawah tanah (subway) dari 75 sen dollar menjadi 85 sen dollar, masyarakat sudah diberitahu enam bulan sebelumnya dan diberi kesempatan untuk menyampaikan keberatan serta ada waktu untuk adu argumentasi. Meskipun akhirnya tetap naik namun masyarakat mendukungnya dengan penuh kesadaran.

Pemberian kesempatan kepada rakyat untuk terlibat dalam proses penentuan kebijakan publik seperti menyampaikan keberatan, beradu argumentasi, adalah 
bagian dari unsur kelima yaitu responsiveness alias sikap tanggáp atau peka:dari kedua belah pihak, pemerintah maupun rakyat. Peka dan tanggap adalah hal yang selama ini masih susah ditemukan dalam pemerintahan Indonesia. Lihat saja betapa rakyat kekurangan infrastruktur yang memadai: air bersih, udara bersih, sanitasi, sarana transportasi umum, ruang-ruang publik, hampir semuanya minimal. Sayangnya, sudah rakyatnya kurang peduli akibat kekurangtahuan, pemerintahnya tidak tampak kesungguhănnya untuk "memajukan kesejahteraan umum dan mencerdaskan kehidupan bangsa." Bahkan ketidaktahuan dan ketidak-pedulian rakyat dimanfaatkan untuk membuat kebijakan yang tidak menguntungkan rakyat. Hal seperti ini yang dipertanyakan oleh Robert $H$. Bates dengan kalimat: "Why should reasonable men adopt policies that have harmful consequences to the societies they govern?" (Mengapa orangorang yang rasional membuat kebijakan yang punya konse-kuensi merugikan bagi masyarakat yang mereka pimpin?). Sikap responsif ini bisa juga diartikan sebagai sikap amar ma'ruf nahi munkar kedua belah pihak. Apabila masyarakat juga berbuat tidak baik seperti berjudi, penyalahgunaan narkoba, dan sebagainya, maka Pemerintah tanggap dan cepat menindaknya.

\section{Penutup}

Dengan proses pemerintahan yang baik, akan terwujud pemerintahan yang bersih. Apabila pemerintahan yang bersih bisa dijalankan dan diwujudkan, maka korupsi yang merupakan penyakit nomor satu di pemerintahan bisa diminimalisasi. Bayangkan, bila kita bisa melakukan penghematan di berbagai bidang kita bisa punya tabungan yang besar. Contoh dari kasus BLBI saja, misalnya, Rp. 145 trilyun akan menjadi lebih dari 18 milyar dollar AS dan itu jumlah yang sangat berarti untuk memajukan bangsa lndonesia khususnya melalui pendidikan. Apabila bangsa ini ikut menjalankan kehidupan yang bersih, semua tindakan koruptif seperti penyelundupan solar, pasir, gula, kayu, dan berbagainya bisa dihentikan dan menjadikannya usaha normal yang menyejahterakan rakyat. Karena itu, sesungguhnya survive-tidaknya bangsa Indonesia tidak berada di tangan IMF. Tidak juga di tangan para pemberi hutang karena justru hutang dari mereka selama ini hampir menjadikan Indonesia tidak survive. Indonesia pasca IMF tetap akan bisa menjalankan pembangunan yang sudah diamanatkan Pembukaan UUD 1945 dengan "memajukan kesejahteraan umum dan mencerdaskan kehidupan bangsa. Syaratnya, sekali lagi, sungguh-sungguh melaksanakan pemerintahan yang baik.

\section{Daftar Pustaka}

Fischer, S., "IMF dan Krisis Asia", Kompas, 6 April 1998.

Mas'oed, Mohtar, Birokrasi, Politik dan Pembangunan, Yogyakarta: Pustaka Pelajar, 1996.

Rahbini, Didik J., Ekonomi Politik: Paradigma dan Teori Pilihan Publik, Jakarta: Ghalia Indónesia, 2002.

www.imf.org/external/np/exr/facts/gov.htm

uww.kompas.com/kompas-cetak/0307/15/ utama/431389.htm

www.rnw.nl/ranesi/html/imf_talak_tiga.html

www.unescap.org/huset/gg/governance.htm

unw.worldbank.org/html/extdr/ offrep/eap/ corgov/amkm6.html 